\title{
KONSEP HASIL TINDAK PIDANA DALAM UNDANG- UNDANG NOMOR 8 TAHUN 2010 TENTANG PENCEGAHAN DAN PEMBERANTASAN TINDAK PIDANA PENCUCIAN UANG
}

\author{
THE CONCEPT OF THE RESULT OF CRIMES IN LAW \\ NUMBER 8 YEAR 2010 ON THE PREVENTION AND \\ ERADICATION OF MONEY LAUNDERING
}

\author{
Syiis Nurhadi \\ Magister Ilmu Hukum Universitas Mataram \\ Email : syiis_nurhadi@yahoo.co.id \\ Rodliyah \\ Universitas Mataram \\ Email : rodliyahfh@unram.ac.id

\section{Any Suryani Hamzah} \\ Universitas Mataram \\ Email : anysuryani@yahoo.com
}

\begin{abstract}
This research aim is to analyse the concept of the result of related crimes in Law Number 8 Year 2010 on the Prevention and Eradication of Money Laundering, this is because many opportunities for the criminal offenders to laundering the money in conducting the money laundering in many sectors. This research is juridical-normative which applied statute and conceptual approaches. Based on the research result, it can be concluded that there are several sectors that produces wealth that originated from other crimes which threatened with four years or more imprisonment i.e in the sectors of Industrial Design, Patent, Trademarks and Geographic Indication, Copyrights, Wakaf, Information and Electronic Transaction, Manpower, Health, Financial, Mining, the Resinous Warehouse, Aviation and the use of Fake Identity.
\end{abstract}

Keywords : Crimes, Money Laundering, the Result of related crimi

\begin{abstract}
Abstrak
Penelitian ini bertujuan untuk menganalisis konsep hasil tindak pidana lain dalam Undang-Undang Nomor 8 Tahun 2010 tentang Pencegahan dan Pemberantasan Tindak Pidana Pencucian Uang, hal ini karena banyaknya peluang para pelaku pencucian uang dalam melakukan aksi pencucian uang di berbagai bidang. Penelitian ini merupakan penelitian yuridis normatif dengan pendekatan perundang-undangan dan pendekatan konseptual. Berdasarkan hasil penelitian yang disimpulkan diketahui bahwa terdapat beberapa bidang yang menghasilkan harta kekayaan yang berasal dari tindak pidana lain yang diancam dengan pidana penjara 4 (empat) tahun atau lebih yaitu di bidang Desain Industri, di bidang Paten, di bidang Merek dan Indikasi Geografis, di bidang Hak Cipta, di bidang Wakaf, di bidang ITE, di bidang Ketenagakerjaan, di bidang Kesehatan, di bidang Keuangan, di bidang Pertambangan, di bidang Sistem Resi Gudang, di bidang Penerbangan, dan Penggunaan Identitas Palsu.
\end{abstract}

Kata kunci : tindak pidana pencucian uang, hasil tindak pidana lain dalam pencucian uang. 


\section{PENDAHULUAN}

Perkembangan praktik ekonomi di Indonesia telah membawa dampak yang baik sekaligus membawa dampak yang tidak baik, dampak baiknya ialah dapat meningkatkan taraf kesejahteraan bagi masyarakat Indonesia. Kemudian dampak negatifnya yaitu tidak menutup kemungkinan praktik ekonomi tersebut dilakukan dengan cara yang kotor atau dengan cara yang curang.

Dalam era globalisasi saat ini, para pelaku usaha tidak hanya menjalankan usahanya secara nasional tetapi juga menjalankan usahanya secara transinternasional, untuk menjaga agar usaha yang dijalankan tetap berjalan dengan baik terkadang para pelaku usaha menjalankan usahanya dengan menghalalkan segala cara. Pelaksanaan usaha dengan cara yang curang dapat mengganggu stabilitas aktivitas ekonomi disuatu negara.

Untuk mengantisipasi hal tersebut maka Pemerintah Indonesia telah memberikan perhatian yang serius terhadap pelaksanaan bisnis kotor, yaitu dengan mengkriminalisasi setiap kegiatan bisnis kotor yang terjadi di Indonesia sebagai suatu tindak pidana. Kriminalisasi bisnis kotor tersebut dikualifikasikan sebagai suatu tindak pidana pencucian uang.

Hal ini terbukti dengan dibuatnya Undang-Undang Nomor 15 Tahun 2002 Tentang Tindak Pidana Pencucian Uang. Salah satu alasan dibuatnya undang-undang tersebut karena meningkatnya kejahatan yang menghasilkan harta kekayaan yang besar sehingga berimplikasi pada stabilitas perekonomian dan keamanan negara.

Tidak berlangsung lama setelah sembilan belas bulan diundangkannya undangundang tersebut, pemerintah indonesia kembali membuat suatu aturan baru mengenai tindak pidana pencucian uang, yaitu Undang-Undang Nomor 25 Tahun 2003 Tentang Perubahan Atas Undang-Undang Nomor 15 Tahun 2002 Tentang Tindak Pidana Pencucian Uang. Perubahan yang dilakukan Pemerintah Indonesia dalam kurun waktu yang bisa dikatakan cukup singkat, membuktikan bahwa praktik pencucian uang merupakan tindak pidana yang memang harus dicegah dan diberantas serta diminimalisir tingkat terjadinya.

Perubahan yang dilakukan terhadap undang-undang tersebut bertujuan agar upaya pencegahan dan pemberantasan terhadap praktik bisns kotor atau praktik pencucian uang dapat dilaksakan secara efektif, serta proses pencegahan dan pemberantasannya harus disesuaikan dengan perkembangan hukum pidana dan standar internasional.

Dalam perkembangan undang-undang tersebut setelah berlaku selama kurang lebih delapan tahun, Pemerintah Indonesia menganggap bahwa praktik pencucian uang tidak hanya mengancam stabilitas perekonomian dan integritas sistem keuangan, tetapi juga dapat membahayakan sendi-sendi kehidupan bermasyarakat, berbangsa, dan bernegara berdasarkan Pancasila dan Undang-Undang Dasar Negara Republik Indonesia Tahun 1945. ${ }^{1}$ Untuk dapat memaksimalkan proses penegakan hukum serta penelusuran terhadap praktik pencucian uang, serta memberikan kepastian hukum dalam upaya pengembalian harta kekayaan dari hasil tindak pidana, maka oleh Pemerintah Indonesia dibuatlah undang-undang baru yaitu Undang-Undang Nomor 8 Tahun 2010 Tentang Pencegahan Dan Pemberantasan Tindak Pidana Pencucian Uang.

Dalam upaya melakukan pencegahan dan pemberantasan serta memaksimalkan proses penegakan hukum terhadap praktik pencucian uang, perlu diketahui terlebih dahulu tentang bentuk-bentuk perbuatan yang dapat dikatakan sebagai tindak pidana pencucian uang. Hal ini karena tidak semua kejahatan dapat dikatakan sebagai tindak

\footnotetext{
${ }^{1}$ Lihat, konsideran menimbang huruf a, UU No. 8 Tahun 2010
} 
pidana pencucian uang. Syarat untuk suatu perbuatan agar dapat dikatakan sebagai tindak pidana pencucian uang adalah harta kekayaan harus berasal dari hasil tindak pidana.

Sementara itu rumusan Pasal 2 ayat (1) Undang-Undang tersebut telah menyebutkan bahwa hasil tindak pidana adalah harta kekayaan yang diperoleh dari tindak pidana seperti $:^{2}$ korupsi, penyuapan, narkotika, psikotropika, penyelundupan tenaga kerja, penyelundupan migran, di bidang perbankan, di bidang pasar modal, di bidang perasuransian, kepabeanan, cukai, perdagangan orang, perdagangan senjata gelap, terorisme, penculikan, penggelapan, penipuan, pemalsuan uang, perjudian, prostitusi, di bidang perpajakan, di bidang kehutanan, di bidang lingkungan hidup, di bidang kelautan dan perikanan, atau tindak pidana lain yang diancam dengan pidana penjara 4 (empat) tahun atau lebih.

Dari uraian di atas, khususnya pada poin terakhir disebutkan bahwa tindak pidana lain yang diancam dengan pidana penjara 4 (empat) tahun atau lebih. Selanjutnya tidak dijelaskan mengenai perbuatan apa saja yang termasuk dalam kategori tindak pidana lain yang diancam dengan pidana penjara 4 (empat) tahun atau lebih dalam penjelasan Undang-Undang tersebut. Artinya bahwa setiap perbuatan yang diancam dengan pidana penjara 4 (empat) tahun atau lebih, yang menghasilkan uang dari perbuatan tersebut dapat diartikan sebagai harta kekayaan aygn diperoleh dari tindak pidana.

Berdasarkan uraian di atas, adapun yang menjadi pokok permasalahan dalam artikel ini yaitu perbuatan apa saja yang termasuk dalam kategori hasil tindak pidana lain dalam Undang-Undang Nomor 8 Tahun 2010 Tentang Pencegahan Dan Pemberantasan Tindak Pidana Pencucian Uang.

Jenis penelitian yang digunakan dalam penelitian ini adalah penelitian yuridis normatif, merupakan penelitian yang mengkaji atau menganalisis peraturan perundangundangan yang berkaitan dengan permasalahan yang sedang diangkat. ${ }^{3}$

Pendekatan penelitian yang digunakan dalam penelitian ini, yaitu meliputi Pendekatan Perundang-Undangan (Statute Approach) dan Pendekatan Konseptual (Cenceptual Approach). Adapun Pendekatan Perundang-Undangan merupakan pendekatan yang menggunakan peraturan perundang-undangan sebagai dasar awal melakukan analisis, pendekatan ini digunakan karena peraturan perundang-undangan merupakan titik fokus dari penelitian ini. ${ }^{4}$ Selanjutnya Pendekatan Koseptual merupakan pendekatan yang beranjak dari konsep-konsep ilmu hukum dalam menganalisis suatu permasalahan, pendekatan ini digunakan karena dalam mengkaji suatu norma hukum dibutuhkan ideide atau pendapat dari para ahli hukum yang digunakan untuk menjawab permasalahan yang diangkat. ${ }^{5}$

Kemudian untuk memudahkan penelitian ini, maka data yang dibutuhkan yaitu bahan hukum primer, bahan hukum sekunder, dan bahan hukum tersier. Adapun bahan-bahan hukum tersebut diperoleh melalui studi kepustakaan (libary research). ${ }^{6}$

\footnotetext{
${ }^{2}$ Lihat, Pasal 2 ayat (1) UU No. 8 Tahun 2010

${ }^{3}$ Taun, Pertanggungjawaban Pidana Korporasi Dalam Tindak Pidana Ketenagakerjaan, Jurnal IUS, Vol. VI, Nomor 2 (Agustus 2018), hlm. 237

${ }^{4}$ Amiruddin \& Zainal Asikin, Pengantar Metode Penelitian Hukum (Edisi Revisi), Rajawali Pers, Jakarta, 2016, hlm. 164

${ }^{5}$ Mukti Fajar \& Yulianto Achmad, Dualisme Penelitian Hukum Normatif \& Empiris, Pustaka Pelajar, Yogyakarta, 2013, hlm. 186

${ }_{6}^{6}$ Muh. Risnain, Konsep Penguatan Kewenangan Komisi Pengawas Persaingan Usaha Sebagai Lembaga Quasi-Peradilan Dalam Membangun Perekonomian Nasional Yang Sehat Dan Adil, Jurnal IUS, Vol. VI, Nomor 2 (Agustus 2018), hlm. 221
} 
Selanjutnya alat analisis yang digunakan dalam penelitian ini yaitu Interpretasi Hukum karena dalam penelitian ini mengandung permasalahan tentang kekaburan norma.

\section{PEMBAHASAN}

\section{Konsep Tindak Pidana Pencucian Uang di Indonesia}

Hukum pidana adalah bagian dari keseluruhan hukum yang berlaku disuatu negara, yang mengadakan dasar-dasar dan aturan-aturan untuk : ${ }^{7}$

1. Menentukan perbuatan-perbuatan mana yang tidak boleh dilakukan, yang dilarang, dengan disertai ancaman atau sanksi yang berupa pidana tertentu bagi barangsiapa melanggar larangan tersebut.

2. Menentukankapandandalamhal-halapakepadamerekayangtelahmelanggarlaranganlarangan itu dapat dikenakan atau dijatuhi pidana sebagaimana yang telah diancamkan.

3. Menentukan dengan cara bagaimana pengenaan pidana itu dapat dilaksanakan apabila ada orang yang disangka telah melanggar larangan tersebut.

Selanjutnya hukum pidana di Indonesia terbagi menjadi dua, yaitu hukum pidana umum dan hukum pidana khusus. Secara definisi hukum pidana umum dapat diartikan sebagai perundang-undangan pidana yang tercantum dalam KUHP, sedangkan hukum pidana khusus dapat dimaknai sebagai peraturan hukum pidana khusus yang diatur di luar KUHP atau di dalam undang-undang tersendiri di luar KUHP. ${ }^{8}$

Pengaturan mengenai Tindak Pidana Pencucian Uang di Indonesia diatur dalam undang-undang tersendiri, yaitu dalam Undang-Undang Nomor 8 Tahun 2010 tentang Pencegahan dan Pemberantasan Tindak Pidana Pencucian Uang. hal ini berarti bahwa Tindak Pidana Pencucian Uang merupakan hukum pidana khusus. Oleh karena itu sebagai tindak pidana khusus, perlu kiranya penulis menjabarkan tentang konsep Tindak Pidana Pencucian Uang yang ada di Indonesia.

1. Sejarah Tindak Pidana Pencucian Uang

Sejarah pencucian uang sebagai suatu tindak pidana telahberkembang sejak dekade 1920-an. Pencucian uang telah menjadi mata rantai penting dalam sistem kejahatan, pelaku-pelaku menyembunyikan hasil kejahatan dalam sistem keuangan atau dalam berbagaibentuk upayalainnya. Tindakan menyembunyikan hasil kejahatan atau danadana yang diperoleh dari tindak pidana dimaksudkan untuk mengaburkan asal usul harta kekayaan. ${ }^{9}$

Dalam perkembangannya pada tahun 1980 -an, praktik pencucian uang menjadi pusat perhatian di dunia barat, terutama dalam konteks kejahatan peredaran obatobat terlarang (psikotropika dan narkotika). Perhatian itu muncul karena besarnya hasil atau keuntungan yang diperoleh dari penjualan obat-obatan terlarang tersebut. Kesadaran akan berbagai dampak buruk yang ditimbulkan oleh praktik pencucian uang telah menjadi penting, karena dengan kemajuan komunikasi dan transportasi membuat dunia terasa semakin sempit, sehingga penyembunyian kejahatan dan hasilhasilnya menjadi lebih mudah dilakukan. ${ }^{10}$

Berdasarkan Konvensi Wina tahun 1988 (United Nation Convention Against Illicit Traffic In Narcotic Drugs and Psychotropic Substances of 1988, the Vienna Convention)

\footnotetext{
${ }^{7}$ Moeljatno, Asas-Asas Hukum Pidana (Edisi Revisi), Rineka Cipta, Jakarta, 2008, hlm. 1

${ }^{8}$ Aziz Syamsuddin, Tindak Pidana Khusus, Sinar Grafika, Jakarta, 2017, hlm. 8

${ }_{9}^{9}$ Ivan Yustiavandana, Arman Nefi \& Adiwarman, Tindak Pidana Pencucian Uang di Pasar Modal, Ghalia Indonesia, Bogor, 2010, hlm. 3

${ }^{10}$ Muhammad Yusuf dkk, Ikhtisar Ketentuan Pencegahan dan Pemberantasan Tindak Pidana Pencucian Uang, National Legal Reform Program, Jakarta, 2011, hlm. 3-4
} 
makalahirlah RezimHukum Anti Pencucianuang, dan mulaimengkriminalisasi tindak pidana pencucian uang untuk pertama kalinya. Dimana diketahui bahwa menikmati atau menggunakan uang hasil kejahatan narkotika dan psikotropika merupakan suatu tindak pidana pencucian uang. ${ }^{11}$

Laporan PBB tahun 1993 mengungkapkan bahwa pencucian harta kekayaan hasil kejahatan yang juga meliputi operasi kejahatan terorganisir dan transnasional adalah bersifat global, fleksibel dan sistem operasinya selalu berubah-ubah, pemanfaatan fasilitas teknologi canggih serta bantuan tenaga profesional, kelihaian para operator dan sumber dana yang besar untuk memindahkan dana-dana haram itu dari satu negara ke negara lain. ${ }^{12}$

Selanjutnya di Indonesia, mulai menganggap praktik pencucian uang sebagai suatu tindak pidana dan menetapkan sanksi bagi para pelakunya adalah pada tahun 2002 . Yaitu ketika diundangkannya Undang-Undang Nomor 15 Tahun 2002 Pencucian Uang pada tanggal 17 April 2002, kemudian diubah dengan Undang-Undang Nomor 25 Tahun 2003. Kemudian dalam perjalanannya menganggap bahwa masih terdapat kekurangan dalam Undang-Undang Nomor 25 Tahun 2003, Pemerintah Indonesia kembali mengganti Undang-Undang tersebutdengan Undang-Undang Nomor 8 Tahun 2010 Tentang Pencegahan Dan Pemberantasan Tindak Pidana Pencucian Uang. ${ }^{13}$

2. Pengertian Tindak Pidana Pencucian Uang

Terdapat beberapa pengertian mengenai pencucian uang atau money laundering, yang dimana diketahuibahwa pengertian tersebuttidakjauhberbeda satusamalainnya. Istilah money laundering pertama kali digunakan di United State of America (USA) pada tahun 1986 oleh Pengadilan Amerikaberkaitan dengan putusantentang penyitaan atas hasil kejahatan narkotika yang dilakukan oleh warga Columbia, kemudian istilah tersebut dipakai secara internasional. ${ }^{14}$

KemudaindalamBlack'sLawDictionarymemberikanpengertiantentangpencucian adalah ${ }^{15}$ istilah untuk menggambarkan investasi di bidang-bidang yang ilegal melalui jaluryang sah, sehingga uang tersebut tidak dapat diketahuilagi asal usulnya. Pencucian uangataumoneylaunderingsecara sederhanadiartikan sebagaisuatuprosesmenjadikan hasilkejahatan (proceed of crimes) ataudisebutsebagaiuangkotor (dirtymoney) misalnya hasil dari korupsi, pengelakan pajak, judi, penyelundupan dan lain-lain dikonversi atau diubah ke dalam bentuk yang tampak sah agar dapat digunakan dengan aman. ${ }^{16}$

Selanjutnya istilah Pencucian Uang menurut Undang-Undang Nomor 8 Tahun 2010 Tentang Pencegahan Dan Pemberantasan Tindak Pidana Pencucian Uang yaitu ${ }^{17}$ segala perbuatan yang memenuhi unsur-unsur tindak pidana sesuai dengan ketentuan dalam Undang-Undang ini.

Adapun unsur-unsur tindak pidana pencucian uang yang dimaksud dalam undangundang tersebut terdiri dari tiga bentuk yaitu :

a. Setiap orang yang menempatkan, mentransfer, megalihkan, membelanjakan, membayarkan, menghibahkan, membawa ke luar negeri, mengubah bentuk, menukarkan dengan mata uang asing atau surat berharga atau perbuatan lain atas

${ }^{11}$ Yenti Garnasih, Penegakan Hukum Anti Pencucian Uang dan Permasalahannya di Indonesia, Rajawali Pers, Jakarta, 2016, hlm. 17

${ }_{12}$ Ibid.

13 BPPK, Sejarah Tindak Pidana Pencucian Uang di Indonesia (https://bppk.kemenkeu.go.id/id/berita-pajak/12562-sejarah-tindak-pidana-pencuciaan-uang-di-indonesia, Diakses Pada 17 Januari 2019)

${ }^{14}$ Yenti Garnasih, Op.Cit. hlm. 17

${ }^{15}$ Ivan Yustiavandana, Arman Nefi \& Adiwarman, Op.Cit. hlm. 10

${ }^{16}$ Margaret Samuel dalam Yenti Garnasih, Op.Cit. hlm. 15

${ }^{17}$ Lihat, Pasal 1 Ayat (1) UU No. 8 Tahun 2010 
Harta Kekayaan yang diketahuinya atau patut diduganya merupakan hasil dari tindak pidana. ${ }^{18}$

b. Setiap orang yang menyembunyikan atau menyamarkan asal usul, sumber, lokasi, peruntukan, pengalihan hak-hak atau kepemilikan yang sebenarnya atas Harta Kekayaan yang diketahuinya atau patut diduganya merupakan hasil dari tindak pidana. ${ }^{19}$

c. Setiap orang yang meneriman atau menguasai penempatan, pentranferan, pembayaran, hibah, sumbangan, penitipan, penukaran, atau menggunakan Harta Kekayaan yang diketahuinya atau patut diduganya merupakan hasil dari tindak pidana. ${ }^{20}$

3. Modus Tindak Pidana Pencucian Uang

Modus dari tindak pidana pencucian sangatlahberagam modelnya,Jeffrey Robinson membagi ke dalam 3 bentuk modus pencucian uang yaitu : ${ }^{21}$

a. Placement (Penempatan Uang), yaitu pelaku tindak pidana memasukkan dana ilegalnya ke rekening perusahaan fiktif seperti perusahaan bidang perhiasan batu berharga, atau mengubah dana menjadi monetary instruments seperti traveler's cheques, money order, dan negotiable instrumens lainnya kemudian menagih uang itu serta mendepositokannya ke dalam rekening (bank accounts)

b. Layering (Pelapisan Uang), yaitu dengan mengirimkan dana ke negara yang menjadi surga bagi dunia perbankan seperti Panama Island, kemudian pada saat uang itu keluar dari negara tersebut maka uang tersebut tersamarkan asal usulnya.

c. Integration/Reparation/Spin Dry (Penyatuan Uang), yaitu dengan memindahkan sejumlah dana yang telah melewati proses pelapisan yang teliti dan kemudian disatukan dengan dana yang berasal dari kegiatan legal ke dalam arus perputaran dana global.

Selanjutnya menurut Yunus Husein yang merupakan mantan Ketua PPATK, menyebutkan ada 5 modus pencucian uang saat dirinya memberikan keterangan ahli di Pengadilan Tipikor Jakarta, pada hari Selasa 09 Oktober 2018 yaitu : ${ }^{22}$

a. Pelaku bersembunyi di dalam perusahan yang dikuasai oleh pelaku. Misalnya, uang haram hasil korupsi dicampur di dalam rekening perusahaan yang menyimpan uang dari sumber yang sah.

b. Pelaku menyalahgunakan perusahaan orang lain yang sah, tanpa sepengetahuan pemiliknya.

c. Pelaku menggunakan identitas palsu. Sebagai contoh, menggunakan KTP palsu atau atas nama orang lain, dengan tujuan menyembunyikan identitas pelaku.

d. Pelaku memanfaatkan kemudahaan di negara lain. Misalnya, tax heaven country. "Menyimpan uang di negara tax heaven supaya susah ditembus informasinya.

e. Pelaku tindak pidana membeli aset tanpa nama. Misalnya uang, perhiasan, lukisan dan benda-benda berharga lainnya.

\section{Konsep Hasil Tindak Pidana Lain Dalam Undang-Undang Nomor 8 Tahun 2010} tentang Pencegahan dan Pemberantasan Tindak Pidana Pencucian Uang

\footnotetext{
${ }^{18}$ Lihat, Pasal 3 UU No. 8 Tahun 2010

${ }^{19}$ Lihat, Pasal 4 UU No. 8 Tahun 2010

${ }^{20}$ Lihat, Pasal 5 UU No. 8 Tahun 2010

${ }^{21}$ Jeffrey Robinson dalam Aziz Syamsuddin, Op.Cit. hlm. 20-21

22 Abba Gabrillin, 5 Modus Pencucian Uang Menurut Mantan Ketua PPATK, (https://nasional.kompas.com/ $\mathrm{read} / 2018 / 10 / 09 / 17004411 /$ ini-5-modus-pencucian-uang-menurut-mantan-ketua-ppatk, Diakses Pada 17 Januari 2019)
} 
Apabila dicermati bunyi dari Pasal 2 ayat (1) huruf z yaitu "tindak pidana lain yang diancam dengan pidana penjara 4 (empat) tahun atau lebih", berarti dapat diketahui terdapat beberapa unsur yaitu:

1. Unsur pertama yaitu "tindak pidana lain yang diancam dengan pidana penjara" selain tindak pidana yang telah disebutkan dalam Pasal 2 ayat (1) huruf a sampai huruf y. Artinya semua tindak pidana lain yang menghasilkan harta kekayaan selain dari yang disebutkan dalam rumusan Pasal 2 ayat (1) huruf a sampai huruf y, merupakan hasil tindak pidana.

2. Unsur kedua yaitu, agar penafsiran terhadap Pasal 2 ayat (1) huruf z tidak terlalu luas, maka dalam rumusan Pasal 2 ayat (1) huruf z memberikan standar minimal khusus terhadap sanksi pidana penjara yaitu "pidana penjara 4 (empat) tahun atau lebih". Artinya semua tindak pidana yang diancam dengan pidana penjara 4 (empat) tahun atau lebih, selain dari yang disebutkan dalam rumusan Pasal 2 ayat (1) huruf a sampai huruf y, merupakan hasil tindak pidana

Adapun harta kekayaan yang diperoleh dari hasil tindak pidana lain yang diancam dengan pidana penjara 4 (empat) tahun atau lebih, selain dari yang disebutkan dalam rumusan Pasal 2 ayat (1) huruf a sampai huruf y Undang-Undang Nomor 8 Tahun 2010 tentang Pencegahan dan Pemberantasan Tindak Pidana Pencucian Uang yaitu terdiri dalam beberapa bidang seperti : tindak pidana lain di bidang Desain Industri, di bidang Paten, di bidang Merek dan Indikasi Geografis, di bidang Hak Cipta, di bidang Wakaf, di bidang ITE, di bidang Ketenagakerjaan, di bidang Kesehatan, di bidang Keuangan, di bidang Pertambangan, di bidang Sistem Resi Gudang, di bidang Penerbangan, dan Penggunaan Identitas Palsu. ${ }^{23}$ Selanjutnya penjelasan dari beberapa bidang tindak pidana lain tersebut yaitu sebagai berikut :

1. Di Bidang Desain Industri

Pemegang hak desain industri memiliki hak eksklusif untuk melaksanakan hak desain industri yang dimilikinya dan untuk melarang orang lain yang tanpa persetujuannya membuat, memakai, menjual, mengimpor, mengekspor dan/atau mengedarkan barang yang diberi Hak Desain Industri. ${ }^{24}$

Sehingga barangsiapa dengan sengaja dan tanpa hak melakukan perbuatan sebagaimana dimaksud dalam Pasal 9 dipidana dengan pidana penjara paling lama 4 (empat) tahun dan/atau denda paling banyak Rp. 300.000.000,00 (tiga ratus juta rupiah). ${ }^{25}$

Sementara itu diketahui bahwa Pasal 9 Undang-Undang tersebut menjelaskan bahwa larangan bagi setiap orang untuk membuat, memakai, menjual, mengimpor, mengekspor dan/atau mengedarkan barang tanpa persetujuan pemegang hak desain industri.

Seperti kasus desain industri helm Bogo, yang dimana diketahui bahwa pemegang hak desain industri dari helm Bogo tersebut adalah Toni berdasarkan catatan Ditjen HKI Kemenkumham dengan nomor registrasi ID0012832D, kemudian di Bogor helm Bogo tersebut diproduksi oleh Gunawan tanpa persetujuan dari Toni. Akibat perbuatan

\footnotetext{
${ }^{23}$ Muhammad Yusuf dkk, Op.Cit. hlm. 254-282

${ }^{24}$ Yuliasih, Perlindungan Hukum Desain Industri Dalam Pelaksanaan Prinsip Keadilan Menurut Teori Keadilan John Rawls (Studi Kasus Putusan Nomor 35PK/PDT.SUS-HKI/2014), Jurnal NOTARIUS, Edisi 08 Nomor 2 (September 2015), hlm. 156

${ }^{25}$ Lihat, Pasal 54 ayat (1) UU No. 31 Tahun 2000
}

\begin{tabular}{ll|l}
78 & IUS & Kajian Hukum dan Keadilan
\end{tabular} 
Gunawan tersebut, Toni mengalami kerugian mencapai Rp. 700.000.000,00 (tujuh ratus juta rupiah). ${ }^{26}$

Berdasarkan kasus tersebut, maka penggunaan desain industri yang telah di daftarkan, dapat dikatakan sebagai tindak pidana lain seperti yang dimaksud dalam Undang-Undang tentang TPPU karena dengan menyalahgunakan atau menggunakan desain industri milik orang lain tanpa persetujuan pemegang hak desain industri dapat memberikan keuntungan bagi pelakunya.

2. Di Bidang Hak Paten

Dalam bidang paten, ada beberapa perbuatan yang dilarang dilakukan tanpa persetujuan atau izin dari pemegang paten, yaitu : ${ }^{27}$

a. Dalam hal paten produk: membuat, menggunakan, menjual, mengimpor, menyewakan, menyerahkan, atau menyediakan untuk dijual atau disewakan atau diserahkan produk yang diberi paten oleh negara.

b. Dalam hal paten proses: menggunakan proses produksi yang diberi paten untuk membuat barang atau tindakan lainnya sebagaimana dimaksud dalam huruf a.

Kedua poin di atas, apabila dilakukan tanpa hak atau tanpa izin dari pemegang paten, maka dapat dijatuhi hukuman pidana sebagai berikut :

1. Setiap orang yang dengan sengaja dan tanpa hak melakukan perbuatan sebagaimana dimaksud dalam Pasal 160 untuk paten, dipidana dengan pidana penjara paling lama 4 (empat) tahun dan/atau denda paling banyak Rp. 1.000.000.000,00 (satu miliar rupiah). ${ }^{28}$

2. Setiap orang yang melanggar ketentuan sebagaimana dimaksud dalam Pasal 161 dan/atau Pasal 162, yang mengakibatkan gangguan kesehatan dan/atau lingkungan hidup, dipidana dengan pidana penjara paling lama 7 (tujuh) tahun dan/atau denda paling banyak Rp. 2.000.000.000,00 (dua miliar rupiah). ${ }^{29}$

3. Setiap orang yang melanggar ketentuan sebagaimana dimaksud dalam Pasal 161 dan/atau Pasal 162, yang mengakibatkan kematian manusia, dipidana dengan pidana penjara paling lama 10 (sepuluh) tahun dan/atau denda paling banyak Rp. 3.500.000.000,00 (tiga miliar lima ratus juta rupiah). ${ }^{30}$

Berdasarkan rumusan Pasal-Pasal diatas, diketahuibahwa setiap orangyang dengan sengaja membuat, menggunakan, menjual, mengimpor, menyewakan, menyerahkan, ataumenyediakanuntuk dijualataudisewakan suatu produkyang telahdiberiHakPaten oleh Negara, terutama menggunakan produk tersebut untuk kepentingan komersial maka dapat dijatuhi sanksi pidana.

3. Di Bidang Merek dan Indikasi Geografis

Adapun sanksi pidana yang diberikan kepada setiap orang yang menggunakan merek tanpa hak eksklusif atau izin dari pemegang Hak atas Merek dengan maksud untuk mendapatkan keuntungan untuk diri sendiri atau oranglain atau suatukorporasi sebagaimana telah diatur dalam Undang-Undang tentag Merek yaitu : ${ }^{31}$

\footnotetext{
${ }^{26}$ Rivki, Akhir Sengketa Kasus Desain Industri Kaca Helm Bogo, (https://news.detik.com/berita/3191631/akhir-sengketa-kasus-desain-industri-kaca-helm-bogo, Diakses pada 17 Januari 2019)

${ }^{27}$ Lihat, Pasal 160 UU No. 13 Tahun 2016

${ }^{28}$ Lihat, Pasal 161 UU No. 13 Tahun 2016

${ }^{29}$ Lihat, Pasal 163 ayat (1) UU No. 13 Tahun 2016

${ }^{30}$ Lihat, Pasal 163 ayat (2) UU No. 13 Tahun 2016

${ }^{31}$ Lihat, Pasal 100 UU No. 20 Tahun 2016
} 
a. Setiap orang yang dengan tanpa hak menggunakan merek yang sama pada keseluruhannya dengan merek yang terdaftar milik pihak lain untuk barang dan/ atau jasa sejenis yang diproduksi dan/atau diperdagangkan, dipidana dengan pidana penjara paling lama 5 (lima) tahun dan/atau pidana denda paling banyak Rp. 2.000.000.000,00 (dua miliar rupiah).

b. Setiap orang yang dengan tanpa hak menggunakan merek yang mempunyai persamaan pada pokoknya dengan merek yang terdaftar milik pihak lain untuk barang dan/atau jasa sejenis yang diproduksi dan/atau diperdagangkan, dipidana dengan pidana penjara paling lama 4 (empat) tahun dan/atau denda paling banyak Rp. 2.000.000.000,00 (dua miliar rupiah).

c. Setiap orangyang melanggar ketentuan sebagaimana dimaksud padaayat(1) danayat (2), yangjenis barangnya mengakibatkangangguankesehatan, gangguanlingkungan hidup, dan/atau kematian manusia, dipidana dengan pidana penjara paling lama 10 (sepuluh) tahun dan/atau denda paling banyak Rp. 5.000.000.000,00 (lima miliar rupiah).

Selanjutnya sanksi pidana yang diberikan kepada setiap orang yang menggunakan tanda yang mempuanyai persamaan dengan Indikasi Geografis tanpa hak eksklusif atau izin dari pemegang Hak atas Indikasi Geografis dengan maksud untuk mendapatkan keuntungan untuk diri sendiri atau orang lain atau suatu korporasi sebagaimana telah diatur dalam Undang-Undang tentag Indikasi Geografis yaitu : ${ }^{32}$

a. Setiaporangyangdengantanpahakmenggunakantandayangmempunyaipersamaan pada keseluruhan dengan indikasi geografis milik pihak lain untuk barang dan/atau jasa produk yang sama atau sejenis dengan barang dan/atau produk yang terdaftar, dipidana dengan pidana penjara paling lama 4 (empat) tahun dan/atau denda paling banyak Rp. 2.000.000.000,00 (dua miliar rupiah).

b. Setiaporangyangdengantanpahakmenggunakantandayangmempuanyaipersamaan pada pokoknya dengan indikasi geografis milik pihak lain untuk barang dan/atau produk yang sama atau sejenis dengan barang dan/atau produk yang terdaftar, dipidana dengan pidana penjara paling lama 4 (empat) tahun dan/atau denda paling banyak Rp. 2.000.000.000,00 (dua miliar rupiah).

Dari rumusan Pasal tersebut di atas, bagi mereka yang menggunakan atau memalsukan Merek dan/atau Indikasi Geografis milik pihaklainyang telah di daftarkan tanpa persetujuan atau izin dari pemilik hak Merek atau Indikasi Geografis maka dapat dijatuhi sanksi pidana.

Seperti yang terjadi di Medan, yang dimana diketahui bahwa ada dua orang yaitu Sugiaty dan Sudermawaty memalsukan Merek Baju Tidur Wanita "Hoki \& Shelia" dengan maksud untuk mendapatkan keuntungan, yang dimana diketahui bahwa Merek Baju Tidur Wanita "Hoki \& Shelia" merupakan Merek milik Veronica Thalib berdasarkan catatan Ditjen HKI Kemenkumham yang terdaftar dengan nomor IDM000020475. Sehingga berdasarkan hal tersebut Veronica mengalami kerugian hingga Rp. 7.000.000.000,00 (tujuh miliar rupiah). ${ }^{33}$

4. Di Bidang Hak Cipta

Adapun sanksi pidana bagi setiap orang yang melakukan penerbitan ciptaan, penggandaan ciptaan dalam segalabentuknya, pendistribusian ciptaanatau salinannya, dan pengumuman suatu ciptaan dengan maksud untuk menguntungkan diri sendiri

${ }^{32}$ Lihat, Pasal 101 UU No. 20 Tahun 2016

${ }_{33}$ Mustakim, Diduga Langgar Hak Merek Dua Pedagang Pakaian di Pusat Pasar diadili, (http://medan.tribunnews.com/2018/01/18/diduga-langgar-hak-paten-dua-pedagang-pakaian-di-pusat-pasar-diadili?page =2, Diakses pada 17 Januari 2019) 
atau orang lain atau suatu korporasi tanpa persetujuan atau izin dari pencipta atau pemegang hak cipta dapat dikenakan pidana sebagai berikut ${ }^{34}$

a. Setiap orang yang dengan tanpa hak dan/atau tanpa izin pencipta atau pemegang hak cipta melakukan pelanggaran hak ekonomi pencipta (penerbitan ciptaan, penggandaan ciptaan dalam segala bentuknya, pendistribusian ciptaan atau salinannya, dan pengumuman suatu ciptaan) secara komersial, dipidana dengan pidana penjara paling lama 4 (empat) tahun dan/atau pidana denda paling banyak Rp. 1.000.000.000,00 (satu miliar rupiah).

b. Setiap orang yang memenuhi unsur sebagaimana dimaksud dalam penjelasan butir huruf a di atas, yang dilakukan dalam bentuk pembajakan dipidana dengan pidana penjara paling lama 10 (sepuluh) tahun dan/atau pidana denda paling banyak Rp. 4.000.000.000,00 (empat miliar rupiah).

Selanjutnya sanksi pidana bagi setiap orang yang melakukan penggandaan atas fiksasi pertunjukan dengan cara atau bentuk apapun, atau melakukan pendistribusian atas fiksasi pertunjukan atau salinannya dengan maksud untuk menguntungkan diri sendiri atau orang lain atau suatu korporasi tanpa persetujuan atau izin dari pencipta atau pemegang hak cipta dapat dikenakan pidana sebagai berikut : ${ }^{35}$

a. Setiap orang yang dengan tanpa hak melakukan pelanggaran hak ekonomi (penggandaan atas fiksasi pertunjukan dengan cara atau bentuk apapun, atau pendistribusian atasfiksasipertunjukanatau salinannya) secara komersial, dipidana dengan pidana penjara paling lama 4 (empat) tahun dan/atau pidana denda paling banyak Rp. 1.000.000.000,00 (satu miliar rupiah).

b. Setiap orang yang memenuhi unsur sebagaimana dimaksud dalam penjelasan butir huruf a di atas, yang dilakukan dalam bentuk pembajakan dipidana dengan pidana penjara paling lama 10 (sepuluh) tahun dan/atau pidana denda paling banyak Rp. 4.000.000.000,00 (empat miliar rupiah).

Selanjutnya sanksi pidana bagi setiap orang yang melakukan penggandaan atas fonogram dengan cara atau bentuk apapun, melakukan pendistribusian atas fonogram asli atau salinannya, melakukan penyediaan atas fonogram dengan atau tanpa kabel yang dapat diakses publik dengan maksud untuk menguntungkan diri sendiri atau oranglain atau suatu korporasi tanpa persetujuan atau izin dari pencipta atau pemegang hak cipta dapat dikenakan pidana sebagai berikut : ${ }^{36}$

a. Setiap orang yang dengan tanpa hak melakukan pelanggaran hak ekonomi (penggandaan atas fonogram dengan cara atau bentuk apapun, pendistribusian atas fonogram asli atau salinannya, penyediaan atas fonogram dengan atau tanpa kabel yang dapat diakses publik) secara komersial, dipidana dengan pidana penjara paling lama 4 (empat) tahun dan/atau pidana denda paling banyak Rp. 1.000.000.000,00 (satu miliar rupiah).

b. Setiap orang yang memenuhi unsur sebagaimana dimaksud dalam penjelasan butir huruf a di atas, yang dilakukan dalam bentuk pembajakan dipidana dengan pidana penjara paling lama 10 (sepuluh) tahun dan/atau pidana denda paling banyak Rp. 4.000.000.000,00 (empat miliar rupiah).

Selanjutnya sanksi pidana bagi setiap orang yang melakukan penyiaran ulang siaran, kamunikasi siaran, fiksasi siaran dan/atau penggandaan fiksasi siaran dengan maksud untuk menguntungkan diri sendiri atau orang lain atau suatu korporasi tanpa

\footnotetext{
${ }^{34}$ Lihat, Pasal 113 ayat (3) dan ayat (4) UU No. 28 Tahun 2014

${ }^{35}$ Lihat, Pasal 116 ayat (3) dan ayat (4) UU No. 28 Tahun 2014

${ }^{36}$ Lihat, Pasal 117 ayat (2) dan ayat (3) UU No. 28 Tahun 2014
} 
persetujuan atau izin dari pencipta atau pemegang hak cipta dapat dikenakan pidana sebagai berikut : ${ }^{37}$

a. Setiaporangyang dengantanpahak melakukan pelanggaran hakekonomi (penyiaran ulang siaran, kamunikasi siaran, fiksasi siaran dan/atau penggandaan fiksasi siaran) secara komersial, dipidana dengan pidana penjara paling lama 4 (empat) tahun dan/ atau pidana denda paling banyak Rp. 1.000.000.000,00 (satu miliar rupiah).

b. Setiap orang yang memenuhi unsur sebagaimana dimaksud dalam penjelasan butir huruf a di atas, yang dilakukan dengan maksud pembajakan dipidana dengan pidana penjara paling lama 10 (sepuluh) tahun dan/atau pidana denda paling banyak Rp. 4.000.000.000,00 (empat miliar rupiah).

Selanjutnya sanksi pidana bagi korporasi atau lembaga manajemen kolektif yang menarik, menghimpun, dan mendistribusikan royalti dengan maksud untuk menguntungkan suatu korporasi tanpa izin dari Menteri dapat dikenakan pidana sebagai berikut : ${ }^{38}$

a. SetiaplembagamanajemenkolektifyangtidakmemilikiizinoperasionaldariMenteri, melakukan kegiatan penarikan royalti, dipidana dengan pidana penjara paling lama 4 (empat) tahun dan/atau pidana denda paling banyak Rp. 1.000.000.000,00 (satu miliar rupiah).

5. Di Bidang Wakaf

Bagi setiap Nazir (pihak yang menerima harta benda wakaf) yang menjaminkan, menyita, menghibahkan, menjual, mewariskan, menukar, atau mengalihkan dalam bentuk pengalihan hak lainnya, dipidana dengan pidana penjara paling lama 5 (lima) tahun dan/atau pidana denda paling banyak Rp. 5.00.000.000,00 (lima ratus juta rupiah), dan bagi Nazir yang mengubah peruntukan harta benda wakaf tanpa izin dari Badan Wakaf Indonesia dipidana dengan pidana penjara paling lama 4 (empat) tahun dan/atau pidana denda paling banyak Rp. 4.00.000.000,00 (empat ratus juta rupiah) ${ }^{39}$

6. Di Bidang ITE

AdapunperbuatanyangdapatdijatuhisanksipidanadalamUndang-Undangtentang ITE, yaitu sebagai berikut :

a. Setiap orang yang dengan sengaja dan tanpa hak mendistribusikan dan/atau mentransmisikan dan/atau membuat dapat diaksesnya informasi elektronik dan/ ataudokumenelektronikyang memilikimuatanyangmelanggarkesusilaan, dipidana dengan pidana penjara paling lama 6 (enam) tahun dan/atau denda paling banyak Rp. 1.000.000.000,00 (satu miliar rupiah).

b. Setiap orang yang dengan sengaja dan tanpa hak mendistribusikan dan/atau mentransmisikan dan/atau membuat dapat diaksesnya informasi elektronik dan/ atau dokumen elektronik yang memiliki muatan perjudian, dipidana dengan pidana penjara paling lama 6 (enam) tahun dan/atau denda paling banyak Rp. 1.000.000.000,00 (satu miliar rupiah).

7. Di Bidang Ketenagakerjaan

Setiap orang yang memperkerjakan anak pada perkerjan terburuk yaitu melakukan perbudakan, memanfaatkan anak untuk palacuran dan/atau pertunjukan pornografi, sertamemanfaatkananakdalamperdagangannarkobadanpsikotropika, sertaperbuatan yang membahayakan kesehatan dan keselamatan anak, dengan maksud mendapatkan keuntungan untuk diri sendiri atau orang lain atau suatu korporasi, dipidana dengan

\footnotetext{
${ }^{37}$ Lihat, Pasal 118 ayat (1) dan ayat (2) UU No. 28 Tahun 2014

${ }^{38}$ Lihat, Pasal 119 UU No. 28 Tahun 2014

${ }^{39}$ Lihat, Pasal 67 ayat (1) dan ayat (2) UU No. 41 Tahun 2004
} 
pidana penjara paling singkat 2 (dua) tahun dan paling lama 5 (lima) tahun dan/atau denda paling sedikit Rp. 2.00.000.000,00 (dua ratus juta rupiah) dan paling banyak Rp. 5.00.000.000,00 (lima ratus juta rupiah) ${ }^{40}$

8. Di Bidang Kesehatan

Setiap orang yang memperjualbelikan organ dan/atau jaringan tubuh dan/atau darah manusia dengan dalih apapun yang bermaksud mengambil keuntungan dari perbuatan tersebut, dikenakan pidana sebagai berikut :

a. Setiap orang yang mengambil keuntungan dengan sengaja memperjualbelikan organ atau jaringan tubuh dengan dalih apapun, dipidana dengan pidana penjara paling lama 10 (sepuluh) tahun dan denda paling banyak Rp. 1.000.000.000,00 (satu miliar rupiah $)^{41}$

b. Setiap orang yang mengambil keuntungan dengan sengaja memperjualbelikan darah dengan dalih apapun, dipidana dengan pidana penjara paling lama 5 (lima) tahun dan denda paling banyak Rp. 5.00.000.000,00 (lima ratus juta rupiah). ${ }^{42}$

Selanjutnya setiap orang yang memproduksi atau mengedarkan sediaan farmasi dan/ataualatkesehatanyang tidak memenuhistandardan/ataupersyaratankeamanan, khasiat atau kemanfaatan dan mutunya, dengan maksud mengambil keuntungan dari perbuatan tersebut, dikenakan pidana penjara paling lama 10 (sepuluh) tahun dan denda paling banyak Rp. 1.000.000.000,00 (satu miliar rupiah). ${ }^{43}$

Selanjutnya setiap orang yang mengambil keuntungan dengan memperkerjakan seorang dokter atau dokter gigi yang tidak memiliki surat izin praktik untuk melakukan praktik kedokteran dapat dipidana dengan pidana penjara paling lama 10 (sepuluh) tahun atau denda paling banyak Rp. 3.00.000.000,00 (tiga ratus juta rupiah) ${ }^{44}$

9. Di Bidang Keuangan

Barangsiapa dengan sengaja, dengan atau tanpa iuran, mengelola dan menjalankan program uang, menjanjikan sejumlah uang yang pembayarannya dikaitkan dengan pencapaian usia tertentu, atau menjalankan kegiatan dana pensiun tanpa mendapat pengesahan dari Menteri, diancam dengan pidana penjara paling lama 5 (lima) tahun dan denda paling banyak Rp. 5.000.000.000,00 (lima miliar rupiah). ${ }^{45}$

10. Di Bidang Pertambangan

Badan usaha pemegangizin panas bumi yang dengan sengaja melakukan eksplorasi, eksploitasi, dan/atau pemanfaatan bukan pada wilayah kerjanya, dipidana dengan pidana penjara paling lama 7 (tujuh) tahun atau pidana denda paling banyak Rp. 70.000.000.000,00 (tujuh puluh miliar rupiah). ${ }^{46}$

Badan usaha yang dengan sengaja melakukan pengusahaan panas bumi untuk pemanfaatan tidak langsung tanpa izin panas bumi dari Menteri, dipidana dengan pidana penjara paling lama 6 (enam) tahun atau pidana denda paling banyak Rp. 50.000.000.000,00 (lima puluh miliar rupiah). ${ }^{47}$

Badan usaha pemegang izin panas bumi yang dengan sengaja menggunakan izin panas bumi tidak sesuai dengan peruntukannya, dipidana dengan pidana penjara paling

\footnotetext{
${ }^{40}$ Lihat, Pasal 183 UU No. 13 Tahun 2003

${ }^{41}$ Lihat, Pasal 192 UU No. 36 Tahun 2009

${ }^{42}$ Lihat, Pasal 195 UU No. 36 Tahun 2009

${ }^{43}$ Lihat, Pasal 196 UU No. 36 Tahun 2009

${ }^{44}$ Lihat, Pasal 80 ayat (1) UU No. 29 Tahun 2004

${ }^{45}$ Lihat, Pasal 56 ayat (1) UU No. 11 Tahun 1992

${ }^{46}$ Lihat, Pasal 70 UU No. 21 Tahun 2014

${ }^{47}$ Lihat, Pasal 71 UU No. 21 Tahun 2014
} 
lama 10 (sepuluh) tahun atau pidana denda paling banyak Rp. 100.000.000.000,00 (seratus miliar rupiah). ${ }^{48}$

11. Di Bidang Sistem Resi Gudang

Setiap orang yang melakukan manipulasi data atau keterangan yang berkaitan dengan resi gudang dan derivatif resi gudang, diancam dengan pidana penjara paling lama 8(delapan) tahundanpidanadendapalingbanyakRp.10.000.000.000,00 (sepuluh miliar rupiah) ${ }^{49}$

Setiaporangyangmelakukankegiatansistemresigudangtanpamemilikipersetujuan dari Badan Pengawas, diancam dengan pidana penjara paling lama 5 (lima) tahun dan pidanadendapalingbanyak Rp. 6.500.000.000,00 (enam miliarlimaratusjutarupiah). ${ }^{50}$

12. Di Bidang Penerbangan

Setiap orang yang mengoperasikan pesawat udara yang tidak mempunyai pendaftaran, dipidana dengan pidana penjara paling lama 5 (lima) tahun atau denda paling banyak Rp. 1.000.000.000,00 (satu miliar rupiah). ${ }^{51}$

13. Penggunaan Identitas Palsu

Setiap orang yang dengan sengaja menjalankan pekerjaan profesi advokat dan bertindak seolah-olah sebagai advokat, tetapi bukan advokat, dipidana dengan pidana penjara paling lama 5 (lima) tahun dan denda paling banyak Rp. 50.000.000,00 (lima puluh juta rupiah). ${ }^{52}$

Semua bidang yang diuraikan di atas, merupakan perbuatan yang apabila dilakukan berpotensi bagi pelakunya untuk mendapatkan keuntungan, sehingga berdarkan unsurunsur dalam ketentuan Pasal 2 ayat (1) huruf z Undang-Undang Nomor 8 Tahun 2010 tentang Pencegahan dan Pemberantasan Tindak Pidana Pencucian Uang, maka 13 (tiga belas) bidang tersebut dapat dikatakan sebagai harta kekayaan yang diperoleh dari tindak pidana lain sebagaimana dimaksud dalam Pasal 2 ayat (1) huruf z UndangUndang Nomor 8 Tahun 2010 tentang Pencegahan dan Pemberantasan Tindak Pidana Pencucian Uang.

\section{SIMPULAN}

Bahwa tindak pidana pencucian uang merupakan suatu perbuatan yang mengancam stabilitas perekonomian dan integritas sistem keuangan disuatu negara, karena perbuatan pencucian uang ini merupakan proses membuat harta kekayaan yang diperoleh dari suatu tindak pidana menjadi harta kekayaan yang tampak berasal dari perbuatan yang sah dengan maksud agar harta kekayaan tersebut dapat digunakan secara aman.

Adapun harta kekayaan yang berasal dari tindak pidana lain yang diancam dengan pidana penjara 4 (empat) tahun atau lebih sebagaimana dimaksud dalam Pasal 2 ayat (1) huruf z Undang-Undang Nomor 8 Tahun 2010 tentang Pencegahan dan Pemberantasan Tindak Pidana Pencucian Uang yaitu terdiri dalam beberapa bidang, yaitu di bidang Desain Industri, di bidang Paten, di bidang Merek dan Indikasi Geografis, di bidang Hak Cipta, di bidang Wakaf, di bidang ITE, di bidang Ketenagakerjaan, di bidang Kesehatan, di bidang Keuangan, di bidang Pertambangan, di bidang Sistem Resi Gudang, di bidang Penerbangan, dan Penggunaan Identitas Palsu.

\section{DAFTAR PUSTAKA}

\footnotetext{
${ }^{48}$ Lihat, Pasal 72 UU No. 21 Tahun 2014

${ }^{49}$ Lihat, Pasal 42 UU No. 9 Tahun 2006

${ }^{50}$ Lihat, Pasal 43 UU No. 9 Tahun 2006

${ }^{51}$ Lihat, Pasal 404 UU No. 1 Tahun 2009

${ }^{52}$ Lihat, Pasal 31 UU No. 18 Tahun 2003
} 


\section{Buku}

Amiruddin \& Zainal Asikin, (2016). Pengantar Metode Penelitian Hukum (Edisi Revisi), Rajawali Pers, Jakarta.

Aziz Syamsuddin, (2017). Tindak Pidana Khusus, Sinar Grafika, Jakarta.

Ivan Yustiavandana, Arman Nefi \& Adiwarman, (2010). Tindak Pidana Pencucian Uang di Pasar Modal, Ghalia Indonesia, Bogor.

Moeljatno, (2008). Asas-Asas Hukum Pidana (Edisi Revisi), Rineka Cipta, Jakarta

Muhammad Yusuf dkk, (2011). Ikhtisar Ketentuan Pencegahan dan Pemberantasan Tindak Pidana Pencucian Uang, National Legal Reform Program, Jakarta.

Mukti Fajar \& Yulianto Achmad, (2013). Dualisme Penelitian Hukum Normatif \& Empiris, Pustaka Pelajar, Yogyakarta.

Yenti Garnasih, (2016). Penegakan Hukum Anti Pencucian Uang dan Permasalahannya di Indonesia, Rajawali Pers, Jakarta.

\section{Jurnal}

Muh. Risnain, (2018). Konsep Penguatan Kewenangan Komisi Pengawas Persaingan Usaha Sebagai Lembaga Quasi-Peradilan Dalam Membangun Perekonomian Nasional Yang Sehat Dan Adil, Jurnal IUS, Vol. VI, Nomor 2.

Taun, (2018). Pertanggungjawaban Pidana Korporasi Dalam Tindak Pidana Ketenagakerjaan, Jurnal IUS, Vol. VI, Nomor 2.

Yuliasih, (2015). Perlindungan Hukum Desain Industri Dalam Pelaksanaan Prinsip Keadilan Menurut Teori Keadilan John Rawls (Studi Kasus Putusan Nomor 35PK/ PDT.SUS-HKI/2014), Jurnal NOTARIUS, Edisi 08 Nomor 2.

\section{Internet}

BPPK, Sejarah Tindak Pidana Pencucian Uang di Indonesia (https://bppk.kemenkeu. go.id/id/berita-pajak/12562-sejarah-tindak-pidana-pencuciaan-uang-diindonesia, Diakses Pada 17 Januari 2019)

Abba Gabrillin, 5 Modus Pencucian Uang Menurut Mantan Ketua PPATK, (https:// nasional.kompas.com/read/2018/10/09/17004411/ini-5-modus-pencucianuang-menurut-mantan-ketua-ppatk, Diakses Pada 17 Januari 2019)

Rivki, Akhir Sengketa Kasus Desain Industri Kaca Helm Bogo, (https://news.detik.com/ berita/3191631/akhir-sengketa-kasus-desain-industri-kaca-helm-bogo, Diakses pada 17 Januari 2019)

Mustakim, Diduga Langgar Hak Merek Dua Pedagang Pakaian di Pusat Pasar diadili, (http://medan.tribunnews.com/2018/01/18/diduga-langgar-hak-paten-duapedagang-pakaian-di-pusat-pasar-diadili?page $=2$, Diakses pada 17 Januari 2019)

\section{Peraturan Perundang-Undangan}

Undang-Undang Republik Indonesia Nomor 11 Tahun 1992 tentang Dana Pensiun (Lembaran Negara Republik Indonesia Tahun 1992 Nomor 37, Tambahan Lembaran Negara Republik Indonesia Nomor 5164) 
Undang-Undang Republik Indonesia Nomor 31 Tahun 2000 tentang Desain Industri (Lembaran Negara Republik Indonesia Tahun 2000 Nomor 243, Tambahan Lembaran Negara Republik Indonesia Nomor 4045)

Undang-Undang Republik Indonesia Nomor 13 Tahun 2003 tentang Ketenagakerjaan (Lembaran Negara Republik Indonesia Tahun 2003 Nomor 39, Tambahan Lembaran Negara Republik Indonesia Nomor 4279)

Undang-Undang Republik Indonesia Nomor 18 Tahun 2003 tentang Advokat (Lembaran Negara Republik Indonesia Tahun 2003 Nomor 49, Tambahan Lembaran Negara Republik Indonesia Nomor 4288)

Undang-Undang Republik Indonesia Nomor 29 Tahun 2004 tentang Praktik Kedokteran (Lembaran Negara Republik Indonesia Tahun 2004 Nomor 116, Tambahan Lembaran Negara Republik Indonesia Nomor 4431)

Undang-Undang Republik Indonesia Nomor 41 Tahun 2004 tentang Wakaf (Lembaran Negara Republik Indonesia Tahun 2004 Nomor 159, Tambahan Lembaran Negara Republik Indonesia Nomor 4459)

Undang-Undang Republik Indonesia Nomor 9 Tahun 2006 tentang Sistem Resi Gudang (Lembaran Negara Republik Indonesia Tahun 2006 Nomor 59, Tambahan Lembaran Negara Republik Indonesia Nomor 4630)

Undang-Undang Republik Indonesia Nomor 1 Tahun 2009 tentang Penerbangan (Lembaran Negara Republik Indonesia Tahun 2009 Nomor 1, Tambahan Lembaran Negara Republik Indonesia Nomor 4956)

Undang-Undang Republik Indonesia Nomor 36 Tahun 2009 tentang Kesehatan (Lembaran Negara Republik Indonesia Tahun 2009 Nomor 144, Tambahan Lembaran Negara Republik Indonesia Nomor 5063)

Undang-Undang Republik Indonesia Nomor 8 Tahun 2010 tentang Pencegahan Dan Pemberantasan Tindak Pidana Pencucian Uang (Lembaran Negara Republik Indonesia Tahun 2010 Nomor 122, Tambahan Lembaran Negara Republik Indonesia Nomor 5164)

Undang-Undang Republik Indonesia Nomor 21 Tahun 2014 tentang Panas Bumi (Lembaran Negara Republik Indonesia Tahun 2014 Nomor 217, Tambahan Lembaran Negara Republik Indonesia Nomor 5585)

Undang-Undang Republik Indonesia Nomor 28 Tahun 2014 tentang Hak Cipta (Lembaran Negara Republik Indonesia Tahun 2014 Nomor 266, Tambahan Lembaran Negara Republik Indonesia Nomor 5599)

Undang-Undang Republik Indonesia Nomor 13 Tahun 2016 tentang Paten (Lembaran Negara Republik Indonesia Tahun 2016 Nomor 176, Tambahan Lembaran Negara Republik Indonesia Nomor 5922)

Undang-Undang Republik Indonesia Nomor 20 Tahun 2016 tentang Merek (Lembaran Negara Republik Indonesia Tahun 2016 Nomor 252, Tambahan Lembaran Negara Republik Indonesia Nomor 5953) 